\title{
SISTEM PENDUKUNG KEPUTUSAN UNTUK SELEKSI PENERIMA BEASISWA BBP-PPA DENGAN METODE TOPSIS BERBASIS WEB
}

\author{
The Decision Support System (DSS) To Select The BBP-PPA Scholarship Awardees By \\ Web-Based-Topsis Method
}

\section{Nova Noor Kamala Sari* \\ Widiatry}

Nadya Chitayae

Universitas Palangka Raya,

Palangka Raya, Central

Kalimantan, Indonesia

*email: novanoorks@it.upr.ac.id

\begin{abstract}
Abstrak
Beasiswa merupakan suatu program pengembangan yang didapatkan mahasiswa untuk terus dapat melanjutkan studi berupa bantuan biaya. Pada Sekolah Tinggi Ilmu Ekonomi Palangka Raya terdapat Beasiswa BBP-PPA untuk membantu mahasiswa yang kurang mampu dalam hal keuangan. Dalam melakukan seleksi beasiswa tersebut pihak Sekolah Tinggi Ilmu Ekonomi Palangka Raya mengalami kesulitan karena banyaknya calon penerima beasiswa. Oleh karena banyaknya jumlah pendaftar tersebut, pihak Sekolah Tinggi Ilmu Ekonomi ingin mempercepat proses penyeleksian dengan melihat satu kriteria saja, yaitu IPK. Proses ini bisa dikatakan tidak tepat karena proses penyeleksiannya cepat dengan melihat satu kriteria saja yaitu ranking IPK. Namun seleksi ini tidak sesuai mengingat ada beberapa kriteria lain yang juga harus dipertimbangkan secara matang. Sehingga, penyelesaian dari masalah ini adalah dibangunnya sebuah Sistem Pendukung Keputusan untuk Menyeleksi Penerima Beasiswa BBP-PPA berbasis web. Sistem Pendukung Keputusan Seleksi Beasiswa ini menggunakan Metode Technique For Order Preference By Similarity To Ideal Solution (TOPSIS). Dalam mengembangkan SPK ini digunakan metodologi pengembangan perangkat lunak Waterfall menurut lan Sommerville. Perangkat lunak yang digunakan dalam membangun website ini adalah Notepad++, SQLyog dan XAMPP. Sistem ini dapat berjalan dengan baik sebagaimana telah dilakukan pengujian blackbox pada sistem.
\end{abstract}

\section{Kata Kunci:}

Sistem Pendukung Keputusan

Beasiswa BBP-PPA

TOPSIS

Waterfall

\section{Keywords:}

Decission Support System

BBP-PPA Scholarship

TOPSIS

Waterfall

Accepted

October 2018

Published

December 2018

\begin{abstract}
The scholarship is a development program obtained by the students to be able to enroll their studies, in the form of financial assistance. At the Economics Institute of Palangka Raya, there is a BBP-PPA Scholarship to help the students who are financially disadvantaged. In selecting the scholarship awardees, Economics Institute of Palangka Raya experienced difficulties due to a large number of prospective scholarship awardees. Because of that, the Economics Institute of Palangka Raya disposes to accelerate the selection process by using one criterion, that is by grading the students' GPA. This process might be inaccurate. Indeed the selection process will be much quicker by that GPA rank criterion. It is inappropriate considering other several criteria that have to be considered carefully as well. Thus, the solution to this problem is to establish the Decision Support System to select the BBP-PPA scholarship awardees which are web-based. The Decision Support System (DSS) uses the Technique for Order Preference Method by Similarity to Ideal Solution (TOPSIS). In developing the DSS, it will apply Waterfall software development methodology as lan Sommerville's. The software used in building this website is Notepad ++, SQLyog, and XAMPP. This system can run well as black box testing on the network.
\end{abstract}

\section{PENDAHULUAN}

Beasiswa merupakan suatu program pengembangan yang didapatkan mahasiswa untuk terus dapat melanjutkan studi. Pada Sekolah Tinggi Ilmu Ekonomi Palangka Raya terdapat Beasiswa Bantuan Biaya Pendidikan Peningkatan Prestasi Akademik (BBP-PPA) untuk mahasiswa yang kurang mampu secara ekonomi tetapi memiliki prestasi yang memadai. Dalam melakukan seleksi beasiswa tersebut pihak Sekolah Tinggi Ilmu Ekonomi Palangka Raya mengalami kesulitan karena banyaknya calon penerima beasiswa. Oleh karena banyaknya jumlah pendaftar tersebut, pihak Sekolah Tinggi Ilmu Ekonomi ingin mempercepat proses penyeleksian dengan melihat satu kriteria saja, yaitu IPK. Padahal ada beberapa kriteria lain yang harus dipertimbangkan dalam mengambil keputusan 
penentuan beasiswa BBP-PPA. Dengan sistem yang dikerjakan secara manual saat ini bisa dikatakan tidak tepat, memang proses penyeleksiannya cepat dengan melihat satu kriteria saja yaitu IPK, tetapi tidak sesuai, mengingat ada beberapa kriteria lain yang juga harus dipertimbangkan secara matang (Priandika, 2016).

Dalam seleksi penerima beasiswa terdapat kriteriakriteria yang telah ditentukan. Mahasiswa/pendaftar sebagai alternatifnya dan prioritas dari kriteria itu sebagai nilai bobot (Kirom et al., 20I2). Dengan menggunakan metode TOPSIS ini nantinya akan mengevaluasi beberapa alternatif berdasarkan sekumpulan atribut atau kriteria (Sutami et al., 2017). Metode TOPSIS merupakan suatu metode pendukung keputusan dengan kriteria yang banyak atau lebih dari satu dimana metode ini memperhatikan solusi ideal positif dan solusi ideal negatif untuk mempertimbangkan mana alternatif yang paling cocok (Suwardika \& Suniantara, 2018).

Peneliti sebelumnya telah melakukan penelitian diantaranya Rancang Bangun Website Sistem Informasi Praktikum Jurusan Teknik Informaktika Universitas Palangka Raya (Widiatry, 2017) yang dapat menambah pemahaman dalam menganalisis dan mendesain suatu sistem. Pengembangan perangkat lunak generate file akun Uang Kuliah Tunggal (UKT) Universitas Palangka Raya (Pranatawijaya et al., 20I8) dapat menambah pemahaman mengenai cara kerja metode pengembangan perangkat lunak bila diimplementasikan ke dalam suatu sistem informasi. Penelitian terbaru adalah Analisis dan Desain Website Monitoring Konsultasi Bimbingan Kartu Rencana Studi (KRS) (Putra et al., 2017) dan Rancang Bangun Sistem Informasi Pencarian Data Mahasiswa dan Dosen pada Fakultas Hukum Universitas Palangka Raya (Putra et al., 2017) memberikan cara untuk pengelolaan data dan pemahaman dalam teknik searching data. Sehingga berdasarkan penelitian sebelumnya tersebut akan melengkapi kajian tentang Sistem Pendukung Keputusan
Seleksi Penerima Beasiswa BBP-PPA dengan menerapkan metode TOPSIS berbasis web untuk Sekolah Tinggi Ilmu Ekonomi Palangka Raya. Berdasarkan permasalahan di atas, maka akan dibuat sebuah Sistem Pendukung Keputusan untuk menyeleksi penerima Beasiswa BBP-PPA menggunakan metode TOPSIS berbasis web untuk Sekolah Tinggi IImu Ekonomi Palangka Raya yang diharapkan dapat membantu menyeleksi penerima beasiswa BBP-PPA berdasarkan kriteria yang ditentukan, bukan hanya bisa dikerjakan dengan proses yang cepat dari sebelumnya tetapi juga dengan penyeleksian yang tepat.

\section{METODOLOGI}

Peralatan yang digunakan meliputi Laptop Sony Vaio $S$ Series VPCSA35GG dengan spesifikasi Intel@ Core (TM) i72640M Processor $2.80 \mathrm{GHz}$ with Turbo Boost up to 3.50 $\mathrm{GHz}$, Memory RAM $6 \mathrm{~GB}$, Hard disk drive $750 \mathrm{~GB}$, dan Windows 7 Professional (64-bit). Software yang digunakan adalah Notepad++, SQLYog, XAMPP, Google Chrome, dan Edraw. Metode Pengembangan perangkat lunak yang digunakan adalah metode Waterfall menurut Sommerville (201I). Waterfall model adalah sebuah contoh dari proses perencanaan, di mana semua proses kegiatan harus terlebih dahulu direncanakan dan dijadwalkan.

\section{Requirement Definition}

Pada tahap ini dilakukan pengumpulan kebutuhan dalam pembangunan Sistem Pendukung Keputusan Seleksi Beasiswa di Sekolah Tinggi Ilmu Ekonomi Palangka Raya untuk kemudian dianalisis. Proses pengumpulan kebutuhan dilakukan secara intensif untuk menspesifikasikan kebutuhan perangkat lunak agar dapat dipahami perangkat lunak seperti apa yang dibutuhkan oleh user.

\section{System and Software Design}

Dalam tahapan ini akan dibentuk suatu arsitektur sistem berdasarkan persyaratan yang telah 
ditetapkan, dan juga mengidentifikasi dan menggambarkan abstraksi dasar sistem perangkat lunak dan hubungan-hubungannya menggunakan Data Flow Diagram (DFD) dan Entity Relationship Diagram (ERD). Pada tahap ini dilakukan desain aplikasi yang meliputi desain interface atau tampilan website dengan menerjemahkan sesuai dengan syarat/kebutuhan ke dalam sebuah representasi aplikasi yang dapat diperkirakan demi kualitas sebelum dimulai pengkodean.

3. Implementation and Unit Testing

Dalam tahapan ini, hasil dari desain perangkat lunak akan direalisasikan sebagai satu set program atau unit program. Setiap unit akan diuji apakah sudah memenuhi spesifikasinya. Desain program diterjemahkan kedalam kode-kode dengan menggunakan bahasa pemrograman yang sudah ditentukan. Program yang dibangun langsung di uji baik secara unit maupun secara keseluruhan program. Perancangan perangkat lunak direalisasikan sebagai serangkaian program atau secara unit program dengan menggunakan bahasa pemprograman PHP dan dengan database MySQL.

4. Integration and System Testing

Dalam tahapan ini, setiap unit program akan diintegrasikan satu sama lain dan diuji sebagai satu sistem yang utuh untuk memastikan system sudah memenuhi persyaratan yang ada. Setelah itu sistem akan dikirim ke pengguna sistem. Unit program atau program individual di integrasikan dan diuji untuk mendeteksi apakah ada bug atau error di dalam Sistem Pendukung Keputusan Seleksi Beasiswa berbasis web ini menggunakan cara pengujian dengan metode Black Box Testing.

5. Operation and Maintenance

Mengoperasikan program di lingkungan dan melakukan pemeliharaan seperti penyesuaian atau perubahan dengan situasi sebenarnya. Biasanya tahap ini merupakan fase siklus yang paling lama meskipun tidak selalu. Pemeliharaan mencakup koreksi dan berbagai kesalahan yang tidak ditemukan pada tahap-tahap sebelumnya (Wijaya et al., 2015).

\section{HASIL DAN PEMBAHASAN}

Sistem ini dibangun menggunakan DFD dan ERD yang digunakan untuk menggambarkan batasan sistem dan fungsi-fungsi sistem secara umum dari Sistem Pendukung Keputusan Seleksi Penerima Beasiswa BBPPPA dengan menggunakan metode TOPSIS Berbasis Web pada Sekolah Tinggi Ilmu Ekonomi Palangka Raya (Perdana \& Widodo, 2013). Diagram Konteks serta ERD disajikan pada Gambar I dan Gambar 2 berikut:

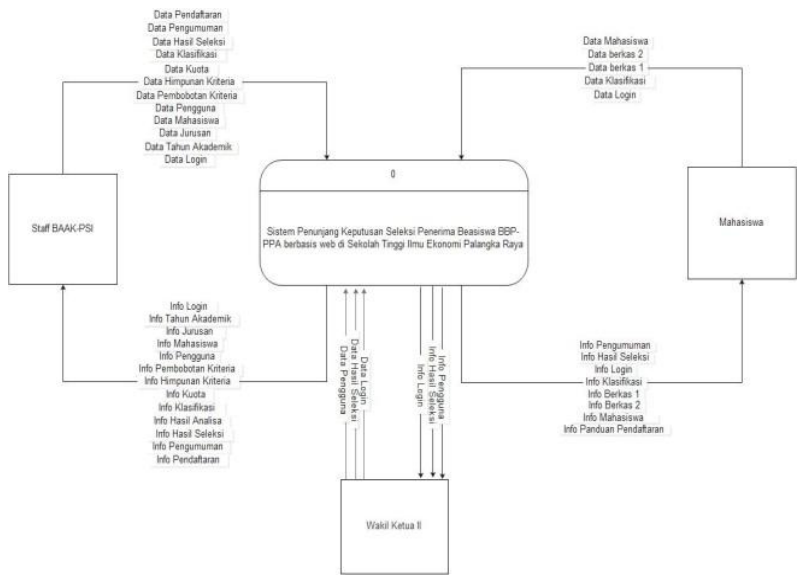

Gambar I. Diagram Konteks

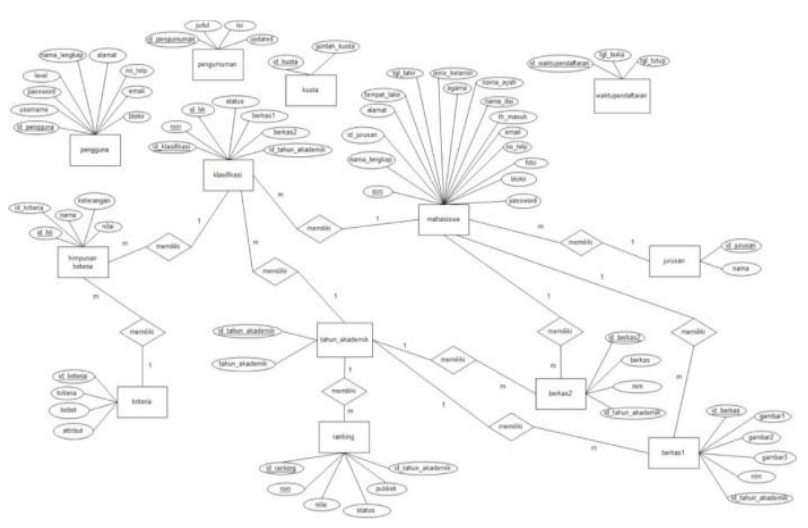

Gambar 2. Entry Relationship Diagram

Desain navigasi menggunakan Sitemap, pada Sistem Pendukung Keputusan berbasis website ini antara lain Sitemap Admin dan Sitemap Mahasiswa yang disajikan pada Gambar 3 sampai Gambar 5 berikut: 


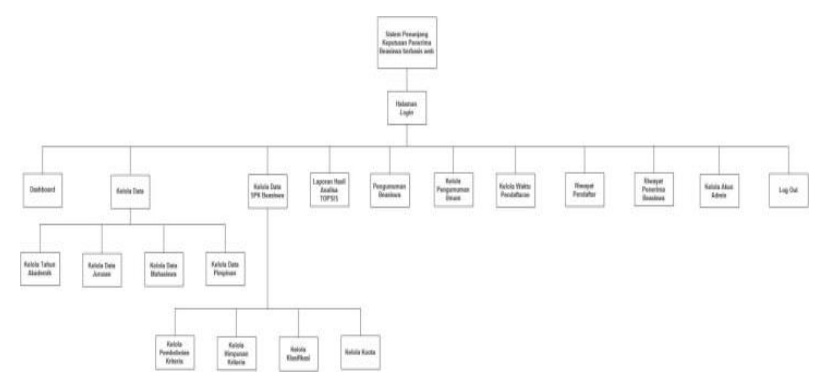

Gambar 3. Sitemap Admin

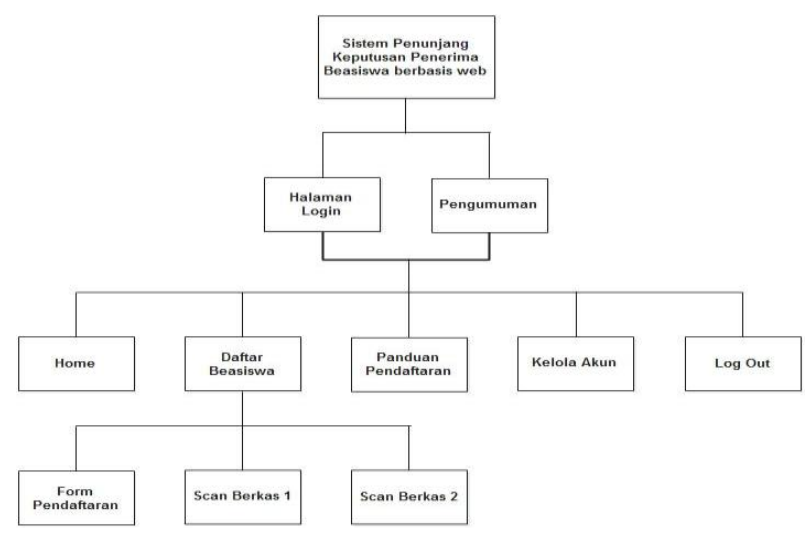

Gambar 4. Sitemap Mahasiswa

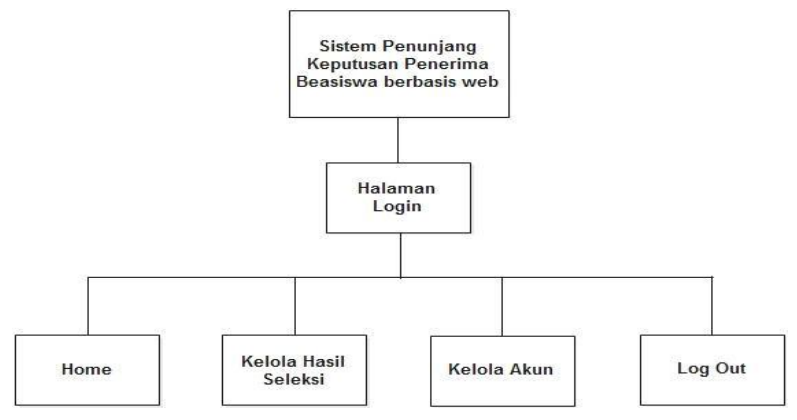

Gambar 5. Sitemap Wakil Ketua II

Kriteria dan Bobot Seleksi Penerima Beasiswa BBP-PPA di Sekolah Tinggi Ilmu Ekonomi Palangka Raya dinyatakan pada Tabel I sebagai berikut:

Tabel I. Kriteria dan Bobot

\begin{tabular}{clc}
\hline Kode & \multicolumn{1}{c}{ Nama Kriteria } & Bobot (\%) \\
\hline Cl & Jumlah Penghasilan Orang Tua & 25 \\
C2 & IPK & 25 \\
C3 & Prestasi Mahasiswa & 15 \\
C4 & Jumlah Tanggungan Orang Tua & 15 \\
C5 & Kepemilikan Rumah & 10 \\
C6 & Jumlah Tagihan Listrik I Bulan & 5 \\
C7 & Terakhir & 5 \\
\hline
\end{tabular}

Berikut beberapa himpunan kriteria dan ratingnya yang digunakan untuk penentuan klasifikasi tiap pendaftar beasiswa BBP-PPA dinyatakan pada Tabel 2 sampai dengan Tabel 8 berikut:

Tabel 2. Kriteria Jumlah Penghasilan Orang Tua (CI)

\begin{tabular}{clcc}
\hline No & \multicolumn{1}{c}{ Himpunan } & Keterangan & Rating \\
\hline I & $0-500000$ & Sangat baik & 5 \\
2 & $500001-1000000$ & Baik & 4 \\
3 & $1000001-3000000$ & Cukup & 3 \\
4 & $3000001-5000000$ & Kurang & 2 \\
5 & $5000001-$ diatas & Sangat & I \\
& 8000000 & Kurang & \\
\hline
\end{tabular}

Tabel 2. Kriteria Jumlah Penghasilan Orang Tua (CI)

\begin{tabular}{clcc}
\hline No & \multicolumn{1}{c}{ Himpunan } & Keterangan & Rating \\
\hline I & $0-500000$ & Sangat baik & 5 \\
2 & $500001-1000000$ & Baik & 4 \\
3 & $1000001-3000000$ & Cukup & 3 \\
4 & $3000001-5000000$ & Kurang & 2 \\
5 & $5000001-$ diatas & Sangat & 1 \\
\hline
\end{tabular}

Tabel 3. Kriteria Indeks Prestasi Akademik (C2)

\begin{tabular}{clcc}
\hline No & \multicolumn{1}{c}{ Himpunan } & Keterangan & Rating \\
\hline I & $3.61-4.00$ & Sangat baik & 5 \\
2 & $3.51-3.60$ & Baik & 4 \\
3 & $3.31-3.50$ & Cukup & 3 \\
4 & $3.01-3.30$ & Kurang & 2 \\
5 & $0-3.00$ & Sangat Kurang & I \\
\hline
\end{tabular}

Tabel 4. Kriteria Prestasi Mahasiswa (C3)

\begin{tabular}{|c|c|c|c|}
\hline No & Himpunan & Keterangan & Rating \\
\hline I & $\begin{array}{l}\text { Nasional - } \\
\text { Internasional }\end{array}$ & Sangat baik & 5 \\
\hline 2 & Provinsi & Baik & 4 \\
\hline 3 & Kabupaten/Kota & Cukup & 3 \\
\hline 4 & Kecamatan/Desa & Kurang & 2 \\
\hline 5 & Tidak ada & Sangat Kurang & $\mathrm{I}$ \\
\hline
\end{tabular}

Tabel 5. Kriteria Jumlah Tanggungan Orang Tua (C4)

\begin{tabular}{clcc}
\hline No & Himpunan & Keterangan & Rating \\
\hline I & Diatas 5 orang & Sangat baik & 5 \\
2 & 4-5 orang & Baik & 4 \\
3 & 3 orang & Cukup & 3 \\
4 & 2 orang & Kurang & 2 \\
5 & I orang/ tidak ada & Sangat Kurang & I \\
\hline
\end{tabular}

Tabel 6. Kriteria Kepemilikan Rumah (C5)

\begin{tabular}{clcc}
\hline No & Himpunan & Keterangan & Rating \\
\hline I & Menumpang & Sangat baik & 5 \\
2 & Sewa Bulanan & Baik & 4 \\
3 & Sewa Tahunan & Cukup & 3 \\
4 & Sewa Harian & Kurang & 2 \\
5 & Pribadi & Sangat Kurang & I \\
\hline
\end{tabular}


Tabel 7. Kriteria Jumlah Tagihan Listrik Sebulan Terakhir (C6)

\begin{tabular}{cccc}
\hline No & Himpunan & Keterangan & Rating \\
\hline I & $0-100000$ & Sangat baik & 5 \\
2 & $100001-150000$ & Baik & 4 \\
3 & $150001-200000$ & Cukup & 3 \\
4 & $200001-300000$ & Kurang & 2 \\
5 & Lebih dari 300000 & Sangat Kurang & 1 \\
\hline
\end{tabular}

Tabel 8. Kriteria Kendaraan Pribadi (C7)

\begin{tabular}{|c|c|c|c|}
\hline No & Himpunan & Keterangan & Rating \\
\hline 1 & Tidak ada & Sangat baik & 5 \\
\hline 2 & Sepeda & Baik & 4 \\
\hline 3 & $\begin{array}{l}\text { Motor tidak lebih } \\
\text { dari } 2\end{array}$ & Cukup & 3 \\
\hline 4 & Motor lebih dari 2 & Kurang & 2 \\
\hline 5 & Ada Mobil & Sangat Kurang & $\mathrm{I}$ \\
\hline
\end{tabular}

Implementasi Halaman Admin

Dalam halaman ini menampilkan header dan sidebar. Pada bagian sidebar merupakan fitur yang dapat diakses oleh admin, yaitu dashboard, kelola data, kelola data SPK Beasiswa, laporan, kelola pengumuman beasiswa, kelola pengumuman umum, kelola waktu pendaftaran, melihat riwayat pendaftar, melihat riwayat penerima beasiswa dan kelola akun. Contoh laman dashboard admin disajikan pada Gambar 6 berikut:

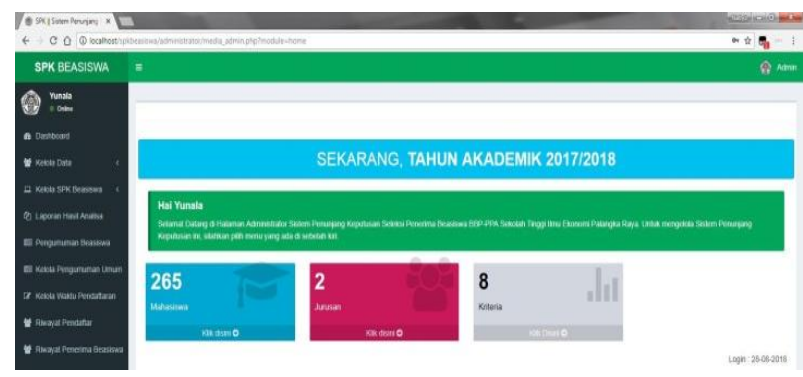

Gambar 6. Halaman Dashboard Admin

Implementasi Halaman Mahasiswa

Dalam halaman ini menampilkan bagian menu website yaitu Home, Daftar Beasiswa, Pengumuman dan Kelola Akun. Contoh laman dashboard mahasiswa disajikan pada Gambar 7 berikut:

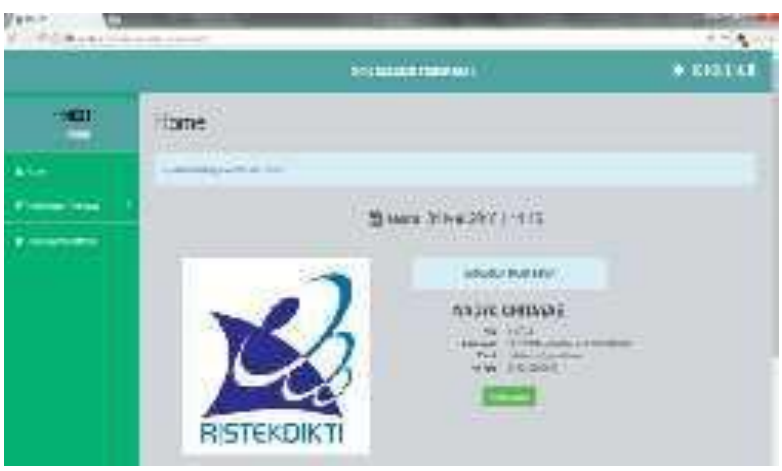

Gambar 7. Halaman Home Mahasiswa

Implementasi Halaman Wakil Ketua II

Dalam halaman ini menampilkan bagian menu website yaitu Home, Kelola Hasil Seleksi dan Kelola Akun. Contoh laman dashboard Wakil Ketua II disajikan pada Gambar 8 berikut:

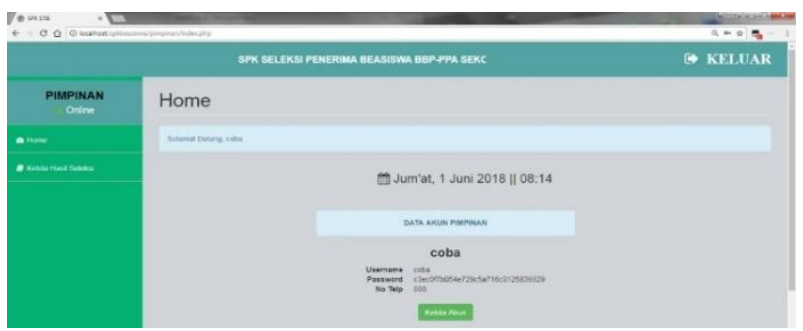

Gambar 8. Halaman Home Wakil Ketua II

\section{KESIMPULAN}

Kesimpulan dari Sistem Pendukung Keputusan Seleksi Penerima Beasiswa BBP-PPA dengan Metode TOPSIS Berbasis Web yaitu sistem ini dibuat dengan menggunakan metode pengembangan perangkat lunak Waterfall. Penelitian diawali dengan mengumpulkan dan mempelajari literatur yang berkaitan dengan teori sistem pendukung keputusan menggunakan metode TOPSIS berbasis web. Tahapan metode TOPSIS yaitu membuat matriks keputusan ternormalisasi, membuat pembobotan matriks yang telah dinormalisasi, menentukan solusi ideal positif dan solusi ideal negatif, menghitung jarak suatu alternatif ke solusi ideal positif dan solusi ideal negatif, dan menghitung nilai preferensi dari setiap alternatif. Sistem diimplementasikan dalam bentuk program berbasis web menggunakan bahasa pemrograman PHP dan MySQL sebagai database. Proses 
terakhir pengujian sistem yang dilakukan antarmuka terhadap user dan program. Maka telah dibangun sebuah Sistem Pendukung Keputusan Seleksi Penerima Beasiswa BBP- PPA berbasis Web yang dapat memberikan informasi berupa hasil seleksi yang berhak mendapatkan Beasiswa BBP-PPA berdasarkan kriteriakriteria yang ditentukan. Sistem Pendukung Keputusan Penerima Beasiswa BBP-PPA berbasis web ini masih dapat dikembangkan dengan menggunakan metode lain seperti metode Weighted Product, Electre, Analytical Hierarcy Process, dan masih banyak metode lain yang dapat diterapkan, sebagai perbandingan antara metode TOPSIS dengan metode- metode tersebut. Selain dalam bentuk web, Sistem Pendukung Keputusan Seleksi Penerima Beasiswa BBP-PPA dapat dibuat versi mobile sehingga memudahkan mahasiswa untuk mengupload file berkas beasiswa dengan cara mengambil foto langsung menggunakan hp tanpa harus scan menggunakan printer dan komputer/laptop.

\section{REFERENSI}

Hendikawati, P. 20II. Analisis Faktor yang Mempengaruhi Indeks Prestasi Mahasiswa. Kreano, Jurnal Matematika Kreatif-Inovatif. 2(I):27-35.

Kirom, D.N., Bilfaqih, Y., \& Effendie, R. 2012. Sistem Informasi Manajemen Beasiswa ITS Berbasis Sistem Pendukung Keputusan Menggunakan Analytical Hierarchy Process. Jurnal Teknik ITS. I (I):I54-I59.

Perdana, N.G. \& Widodo, T. 20I3. Sistem Pendukung Keputusan Pemberian Beasiswa Kepada Peserta Didik Baru Menggunakan Metode TOPSIS. In Seminar Nasional Teknologi Informasi \& Komunikasi Terapan 2013. Semarang: Universitas Dian Nuswantoro.

Pranatawijaya, V.H., Putra, P.B.A.A., Widiatry, \& Sari, N.N.K. 2018. Pengembangan Perangkat Lunak Generate File Akun Uang Kuliah Tunggal (UKT) Universitas Palangka Raya. Jurnal Saintekom: Sains, Teknologi, Komputer dan Manajemen. 8(2): I66-I78.

Priandika, A.T. 2016. Model Penunjang Keputusan Penyeleksian Pemberian Beasiswa Bidikmisi menggunakan Metode Analytical Hierarchy Process. Jurnal Teknoinfo. 10(2): I-6.

Putra, P.B.A.A., Sari, N.N.K., Pranatawijaya, V.H. 2017. Analisis dan Desain Website Monitoring Konsultasi Bimbingan Kartu Rencana Studi (KRS). Jurnal Teknologi Informasi. I I ( I):58-68.

Putra, P.B.A.A., Pranatawijaya, V.H., Widiatry, \& Lisa. 2017. Rancang Bangun Sistem Informasi Pencarian Data Mahasiswa dan Dosen pada Fakultas Hukum Universitas Palangka Raya. Jurnal Teknologi Informasi. I I(2):36-45.

Sutami, S., Soedjiono, B., \& Henderi, H. 2017. Evaluasi Kualitas Layanan Web Menggunakan Model Integrasi Fuzzy AHP-TOPSIS. Jurnal Teknologi Informasi. I2(34):92-99.

Suwardika, G. \& Suniantara, I.K.P. 20I8. Penerapan Metode VIKOR pada Pengambilan Keputusan Seleksi Calon Penerima Beasiswa Bidikmisi Universitas Terbuka. Intensif: Jurnal Ilmiah Penelitian Teknologi dan Penerapan Sistem Informasi. 2(I):24-35.

Widiatry. 2017. Rancang Bangun Website Sistem Informasi Praktikum pada Jurusan Teknik Informatika Univeritas Palangka Raya. Jurnal Teknologi Informasi. I I (I):76-85.

Wijaya, K., Wowor, H., \& Tulenan, V. 20I5. Sistem Pendukung Keputusan Penerima Beasiswa Dengan Metode Technique for Order Preference by Similarity to Ideal Solution di Universitas Sam Ratulangi Manado. Jurnal Teknik Informatika. 5(I): I-6. 